\title{
IMPLEMENTATION OF LEAN MANUFACTURING TOOL 5S TO IMPROVE PRODUCTIVITY IN BTIRT CAMPUS
}

\author{
Sandeep Katare \\ Department of Mechanical \\ BTIRT, Sagar, M.P, India.
}

\author{
Tarun Kumar Yadav \\ Department of Mechanical \\ BTIRT, Sagar, M.P, India.
}

\begin{abstract}
The significance of education in the development of a nation cannot be underestimated. The education that develops capability, brilliance, and acquaintance that leads to the worldwide economy improvement. It is a major concern for Indian Higher education institutes that they should also adopt quality measures for improving the quality of education. $5 \mathrm{~S}$ is a systematic technique used by manufacturing as well as service organizations. The $5 \mathrm{~S}$ process is the most fundamental component of the lean philosophy. $5 \mathrm{~S}$ is the starting of a productive life for everyone. The present research studies the implementation of $5 \mathrm{~S}$ in higher education institute. An implementation of $5 \mathrm{~S}$ in an organization helped to maintain and organize the environment by because of which there was tremendous change in workspace, reduction in wastage, quality and yield of production was increased through monitoring and structured environment.
\end{abstract}

Keywords-5's, TQM, JIT, Lean Tools

\section{INTRODUCTION}

The significance of education in the development of a nation cannot be underestimated. It is education that develops expertise, excellence, and knowledge that lead to the universal development of any economy. This has created a necessity to develop strategies for the development of higher education in almost all the countries of the world ${ }^{[1]}$. Thus the success of higher education institutions depends on how the educational leaders work to implement the strategies. Higher education, on one hand, can effectively provide the qualified human resource in the form of committed professionals to develop the economy of a country and on the other hand good citizens with great values to balance economic and cultural development of the nation. However, the quality measures play an important role in the education provided by the higher education institutes. Therefore it becomes important to assure quality with sustainable improvement in higher education. Universities and higher education institutes in India are also adopting quality measures to improve the quality of education. India has the third largest higher education sector in the world.
However, only a few higher education institutes like Indian Institutes of Technology and Indian Institutes of Management are providing world-class education ${ }^{[2]}$. Realizing the fast growth of the education sector in India, many private companies are looking for relevant acquisitions and alliances in this space. Major investments are being seen in the areas of pre-schools, higher education institutes, private coaching and tutoring, teacher training, development and provision of multimedia content, educational software development, skill enhancement, IT training and e-learning.

\subsection{Lean Philosophy}

Lean is essentially a set of ideas and tools that make up a complex interdependent system which has both visible and invisible parts. The main principle of lean manufacturing is to reduce cost through continuous improvement that will eventually reduce the cost of services and products, thus growing more profits. The basic ideas behind the lean philosophy are waste elimination, cost reduction, and employee empowerment ${ }^{[3]}$.

Lean is the systematic approach to identifying and eliminating waste through continuous improvement by flowing the product or service at the pull of your customer in pursuit of perfection $^{[4]}$.

\subsection{Lean Tools}

The most important lean management tools are 5S, Just-InTime (JIT), Kaizen, Kanban, Poka-Yoke, One Piece Flow, FMEA, Single Minute Exchange of Die (SMED), Total Productive Maintenance (TPM), Total Quality Management (TQM), Value Stream Mapping and Standard Work.

\subsubsection{S}

The 5S methodology is a simple and universal approach that works in companies all over the world. It is essentially a support to such other manufacturing improvements as just-intime (JIT) production, cellular manufacturing, Total Quality Management (TQM), or six sigma initiatives, and is also a 
great contributor to making the workplace a better place to spend time ${ }^{[5]}$.

\subsubsection{Total Quality Management}

Total quality management is a management approach used to achieve quality improvement and long-term success through customer satisfaction. TQM involves all members of the organization and is meant to improve the quality of all processes, products, services, operations, and corporate culture [6].

\subsubsection{Just-In-Time}

The basis of Just-In-Time (JIT) is the concept of ideal production. It centers on the elimination of waste in the whole manufacturing environment, from raw materials through shipping. Just-In-Time is defined as "the production of the minimum number of different units, in the smallest possible quantities, at the latest possible time, thereby eliminating the need for inventory.

\subsubsection{Kaizen}

Kaizen is a solid strategic instrument which is used to achieve and overcome the company's objectives. The Kaizen method and technique are valuable instruments that can be used to increase productivity to obtain a competitive advantage and to raise the overall business performance ${ }^{[7]}$.

\subsubsection{Poka-Yoke}

Poka-Yoke is a quality assurance technique developed by Japanese manufacturing engineer Shigeo Shingo. The aim of Poka-Yoke is to eliminate defects in a product by preventing or correcting mistakes as early as possible.

\subsubsection{Value Stream Mapping}

The Value stream mapping (VSM) process allows you to create a detailed visualization of all steps in your work process. It is a representation of the flow of goods from supplier to customer through your organization.

\subsubsection{Kanban}

Kanban is a visual system for managing work as it moves through a process. Kanban visualizes both the process (the workflow) and the actual work passing through that process.

\subsection{Research Objective}

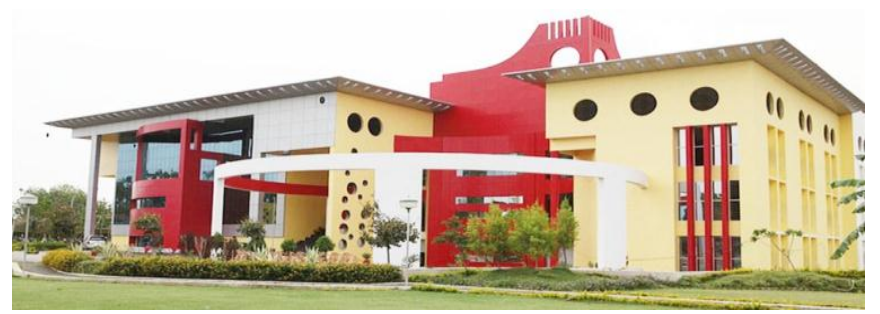

The objective of this study was to Implement and evaluate the impact of $5 \mathrm{~S}$ in a BTIRT.

To improve the quality of education and placement activities, the AICTE has to monitor the institution to improve in the field of higher education as per the following tasks.

- To decide mission and goals of a private higher education institutions. The measurements are obtained and verified after every academic semester/year by the AICTE.

- To determine the accreditation requirements of private higher education institution, and follow-up quality assurance measures in every year.

- To adopt universal standards for licensure and accreditation.

- To establish measures of accreditation and validation of academic degrees issued by the private institutions.

- To oversee the sustainability of private institutions and provide advice.

\section{LITERATURE REVIEW}

5S is a simple and effective Lean thinking methodology that focuses on a visible task environment. Hirano founded 5S and Osada introduced it at Toyota in 1970 (Hirano, 1995). 5S is considered to increase the environmental performance in the production line such as housekeeping, health, and safety (Hirano, 1995; Rahman et al., 2010; Razzak, 2013). Moreover, important in $5 \mathrm{~S}$ is self-ordering, self-improving, and selfexplaining ${ }^{[8]}$.

According to Boca (2011), 5S is not only a system for housekeeping, but it is also an integrated approach for productivity improvement. $5 \mathrm{~S}$ is a whole a culture which increases production, improves quality, reduces cost, makes delivery on time, improves safety and improves morale ${ }^{[7]}$.

Kilpatrick (2003) in their study shows $5 \mathrm{~S}$ is a systematic method for organizing and standardizing the workplace. It's one of the simplest Lean tools to implement, provides an immediate return on investment, crosses all industry boundaries, and is applicable to every function with an organization. Because of these attributes, it's usually our first recommendation for a company implementing Lean ${ }^{[9]}$.

The $5 \mathrm{~S}$ techniques are fundamental techniques which allow the increase of efficiency and productivity while ensuring a pleasant organizational climate. A better relationship with suppliers was created, workers at all levels were trained and empowered, awareness was created and ultimately brought a cultural change throughout the organization through $5 \mathrm{~S}^{[10] \text {. }}$

After the implementation of 5S, employee morale was improved, financial resources increased by selling unused, old or unnecessary equipment, efficient coordination at all levels in the organization and increased resource utilization (Veza et al., 2011). 5S along with Pareto analysis identified and solved $80 \%$ of the storage space problems in an equipment storage area (Balle \& Regnier, 2007). 5S is not a trend in fashion (Flinchbaugh, 2006). 5S is a systematic Lean tool and the simplest to implement for organizing and standardizing the workplace [ ${ }^{11]}$ 
Santamaria (2012) 5S methodology is considered one of the basic principles of the Lean-to maximize efficiency in the workplace, and to have the possibility of product diversification, higher quality, lower costs, reliable deliveries, etc. The implementation of $5 \mathrm{~S}$ allows the formation of habits of cleanliness and order between operators, technical, administrative and managerial. By using the technique of $5 \mathrm{~S}$ in the business, we are referring to the implementation of the same to maintain jobs and other areas of a company clean, orderly and only the necessary. The 5S's are the foundation of industrial productivity model created in Japanese and Western companies applied today. The $5 \mathrm{~S}$ philosophy is not a current improvement of work but a philosophy applies to all levels in our everyday life in today's society. ${ }^{[12]}$

In the past, several organizations have successfully implemented 5S. Researchers have shared their experience during the implementation of $5 \mathrm{~S}$ and its impact after the event. Zidel (2006) suggested that $5 \mathrm{~S}$ creates a solid foundation for future Lean initiative and can be implemented by any organization. Esain et al. (2008) identified $5 \mathrm{~S}$ as a structural method to speed up operational change and focused on overseeing workplace discipline and control. Similarly, the study conducted by Khamis et al. (2009) also focused on a structural method to transform the $5 \mathrm{~S}$ process by providing adequate training to the employees starting with input for $5 \mathrm{~S}$ to the result. ${ }^{[13]}$

People do not need to have a high education to run 5S. Any position of the employees in the organization can certainly do it. Anyone in the company should understand and practice $5 \mathrm{~S}$ (Skaggs, 2010). A lot of studies show many benefits once the company runs $5 \mathrm{~S}$ such as creating organized workplaces (Skaggs, 2010), promoting the clean work environments (Barker, 2008), improving safety and increased product quality and productivity (Prabwo, N., 2011). 5S should be considered an everyday continuous improvement activity for individuals and small groups ${ }^{[14]}$

Running 5S can be divided into three sections which create a structured process for the project, make a clean environment, and create a clear method of management for the project (Rowlinson, 2004). If companies do 5S in the right way, it will help the company to have a smooth operation; hence, all the employees will be happy to remain with the new process in order to have a better environment ${ }^{[15]}$

$5 \mathrm{~S}$ is a component of Lean Manufacturing. One of the fundamental steps to begin a successful Lean initiative is implementing 5S (Cooper et al, 2007). The 5Ss are often referred to as the foundation blocks, or pillars, upon which a company can build its lean initiative (Lanigan, 2004) because $5 \mathrm{~S}$ creates a good visual factory ${ }^{[16]}$

Three fundamental things to keep in mind while developing a $5 \mathrm{~S}$ program are according to Cooper et al. (2007) $5 \mathrm{~S}$ is about consistency and continuity. It is a systematic method for involving and empowering employees. 5S employs visual management and enables a person to recognize abnormalities at a glance. ${ }^{[16]}$
Implementation of 5Ss leads to benefits such as less searching, decreased walking and motion, reduced downtime, fewer safety hazards and accidents, improved flow, fewer mistakes, and better utilization of space (Chapman, 2005). This framework also improves safety in the workplace, and according to Hirano without the organization and discipline provided by implementing 5 Ss other lean tools and methods will probably fail ${ }^{[17]}$.

$\mathrm{Wu}$ et al. (2011) have reviewed the successful implementation of 5Ss benefits both the workers and the organization. The workers enjoy a more pleasant work environment and find their jobs more satisfying. The organization experiences better quality and improved maintenance. This results in cost reductions and improved profitability. The successful implementation of 5Ss requires the introduction of change management. To avoid the $5 \mathrm{~S}$ program falling apart, management needs to support this program, perform regular audits, and award workers for their efforts through a reward system. Implementing 5Ss is not easy and requires a thoughtful process, good leadership, and management capabilities. ${ }^{[18]}$

Steve Lage, (Wu et al., 2011)President of PDG Consultants, Inc. suggests that to achieve success in 5Ss it is better to start small, and keep the focus tight and confined to one manageable area. Go an inch wide and a mile deep. Raise the level of 5Ss so high that people can't help but notice. Develop and practice sustainment skills before you begin work in the next area. It does you no good to run rampant through the factory or office if you can't sustain. Use your success to set 5Ss expectations for each area of the business and move through the entire company one step at a time. Remember that the most challenging and important part of 5Ss is to change behavior ${ }^{[18]}$.

Esain et al. (2008) identified $5 \mathrm{~S}$ as a structural method to speed up operational change and focused on overseeing workplace discipline and control. Similarly, the study conducted by Khamis et. al (2009) also focused on a structural method to transform the $5 \mathrm{~S}$ process by providing adequate training to the employees starting with input for $5 \mathrm{~S}$ to the result $^{[19]}$.

Gapp et al. (2008) Regardless of the organization size or type, $5 \mathrm{~S}$ can be used for improvement activities within environments such as homes, schools, communities, and workplaces ${ }^{[20]}$.

Jimenez et al. (2015) point out the experience in $5 \mathrm{~S}$ methodology implementation in order to optimize the work and safety of the university engineering laboratories. Learning, control and maintenance of the resources and activities involved were performed in less time and with a considerable reduction of cost after the implementation of $5 \mathrm{~S}$. There was an increase in available space for the location of the resources. The researcher concludes that the introduction of the $5 \mathrm{~S}$ methodology leads to systematic risk reduction ${ }^{[21]}$. 
Johana Y. et al. (2014) discovered the difference of attitude among its administration staff after the implementation of Quality Environment (QE) /5S and to identify how this process could provide better services to the client. It also looked at the improvement needed to be done to ensure the sustainability of QE/5S in the workplace. Quantitative and qualitative methods are used in this study to explore the gap between the attitude of the staff and sustainability in the implementation of $\mathrm{QE} / 5 \mathrm{~S}$. This research contributes to the knowledge of the importance of QE/5S and steps that need to be taken in order to sustain the implementation of QE/5S towards a better workplace environment in the future. It concludes that the application of $5 \mathrm{~S}$ at the workplace helped in improving safety, work efficiency, productivity and a sense of ownership among the administrative staff ${ }^{[22]}$.

Radnor and Bucci (2011) highlight the main findings from an independent analysis of the implementation of the Lean improvement methodology in Business Schools and Universities in the United Kingdom. It says that lean has expanded beyond manufacturing to become an improvement methodology firstly in the service sector and more recently in public sector organizations looking towards improving efficiency and customer value. The data collection was done through semi-structured interviews with individuals in five Business Schools and Universities known to be involved in Lean implementation ${ }^{[23]}$.

Maggie and Liu (2006) share the experience of implementing the $5 \mathrm{~S}$ system in a library which serves as a reference to the library association in the continuous improvement of the library environment. It also attempts to analyze the validity of "library as place" and its compatibility with the impact of information technology development. The work concludes that the 5S system provides a framework and guidelines for creating and maintaining a congenial and pleasant environment for library staff ${ }^{[24]}$.

Skaggs (2010) 5S classifies the work environment, reduces waste and non-value activity while improving quality, efficiency, and safety. These processes can increase morale, create positive impressions on customers, and increase efficiency and organization. 5S makes employees feel better about their work environment. This improvement leads to less waste, better quality and reduced lead times. Any of these benefits will make a company more profitable and competitive in the market place ${ }^{[25]}$.

Maidhili et al. (2014) on the Kaizen formula and 5S of Japanese strategies focuses on the improvement in space management of any organization. This paper explains about the various aspects focus on $5 \mathrm{~S}$ in detail. According to the study, $5 \mathrm{~S}$ engages people through the use of standards and discipline. It concludes that $5 \mathrm{~S}$ creates space for better utilization in a library ${ }^{[26]}$.

According to economic surveys and budget documents (2016), education and skill development are crucial for reaping the demographic dividend. The market size of the Indian education sector is expected to increase to Rs 602,410 crore
(US\$ 95.80 billion) by 2014-15 on the back of strong demand for quality education, according to a report by India Ratings. Indian education sector's market size in 2011-12 has estimated at Rs 341,180 crore (US\$ 54.20 billion). The sector grew at a compounded annual growth rate (CAGR) of 16.5 percent during 2004-05 to 2011-12 ${ }^{\text {[27] }}$.

Considering the importance of education and skill development, the Government of India has set itself an aggressive target of achieving 30 percent gross enrolment ratio (GER) in higher education by 2020, which translates into doubling the GER in the next eight years. According to the Ministry of Human Resource and Development data, enrolments have increased from 15.5 million (GER of 12.4 percent) in 2006-07 to 17.3 million (GER of 15 percent) in 2009-10 and further increased to 27.5 million (GER 19.4 percent) in $2010-11^{[28]}$.

From the words of Brady (2014), 5S is nothing like just putting things in order around you, and that is clear and simple for workers. $5 \mathrm{~S}$ is a powerful quality tool for everyone to get involved in the improvement process ${ }^{[29]}$.

Olofsson (2015) pays attention to the fact that working after a standard that is always being improved is a supporting pillar of successful concepts like Lean Manufacturing and Total Quality Management, so one can consider 5S as the first step on this way ${ }^{[30]}$.

Being action oriented, 5S is a powerful quality tool for everyone to get involved in the improvement process. Therefore, it is a very effective way to implement a new management paradigm. Based on the experience derived from the implementation of the comprehensive quality management system and through in-depth research in Hong Kong, Japan, and the UK, Ho (2007) has identified the 5S practice as the step number one for a TQM/BE program. He realized that $5 \mathrm{~S}$ is an important step towards process improvement, the key to ISO 9000, ISO 14000 and OHSAS 18001 and can be used as an integrating tool towards Business Excellence ${ }^{[31]}$.

\section{RESEARCH METHODOLOGY}

The purpose of this research was to explore and identify an effective approach to implement the Lean tool $5 \mathrm{~S}$ that will improve the productivity, quality and morale of staff of BTIRT. The goals were to arrange store and record room, proper utilization of laboratories and to optimize the usage of library space. Implementation of $5 \mathrm{~S}$ gives a process to reorganize the plan and enhance the regulation. This study focused on how to use $5 \mathrm{~S}$ to reorganize the place of work and improve effectiveness. This chapter will describe each step and how $5 \mathrm{~S}$ works entirely in the institute.

\subsection{Present Condition of College:}

The College BTIRT has 3 floors, workshop, canteen, mess, girl's hostel,boy's hostel, faculty quarters and servant quarters. 


\section{International Journal of Engineering Applied Sciences and Technology, 2019 \\ Vol. 4, Issue 4, ISSN No. 2455-2143, Pages 55-62 \\ Published Online August 2019 in IJEAST (http://www.ijeast.com)}

1) Ground Floor:

2) First Floor:

3) Second Floor:

4) Third Floor:

5) Workshop

\subsection{S Effectiveness Measurement}

1) Travelling Time

2) Floor Space Utilization

3) Searching Time

\subsection{Research Question and Hypothesis}

The research question in this study was to implement and evaluate the impact of $5 \mathrm{~S}$ in a higher education institute. This study used the questionnaires to understand the changes in employee's efficiency before and after the implementation of the $5 \mathrm{~S}$ event.

Hypotheses are defined to confine the statistical analysis of the specific research questions. There are four hypotheses considered in this research study. These hypotheses tested the effects of $5 \mathrm{~S}$ implementation on the higher education institute. Ho1: 5S will not increase the arrangements in the administrative office.

Ha1: 5S will increase the arrangements in the administrative office.

Ho2: $5 \mathrm{~S}$ will not increase the arrangements in the storeroom.

$\mathrm{Ha} 2$ : 5S will increase the arrangements in the storeroom.

Ho3: 5S will not increase the arrangements in the library.

Ha3: 5S will increase the arrangements in the library.

Ho4: 5S will not increase the arrangements in laboratories.

Ha4: 5S will increase the arrangements in laboratories.

\subsection{Participants}

The participants included the academic staff, management/ administrative staff, and lab technicians/ other staff of BTIRT which were directly affected by the $5 \mathrm{~S}$ implementation. The total number of participants was 30 .

\subsection{Questionnaires Survey}

Table 3.1 Questionnaires components

\begin{tabular}{|l|l|}
\hline Components & No. of Questions \\
\hline Administrative office & 7 \\
\hline Storeroom & 6 \\
\hline Library & 9 \\
\hline Laboratories & 8 \\
\hline
\end{tabular}

\begin{tabular}{|l|l|}
\hline Total & 30 \\
\hline
\end{tabular}

The participants were required to answer all 30 questions with Likert 5-Point scale. Show in the table 3.2.

Table 3.2 Likert Scale

\begin{tabular}{|l|l|l|l|l|l|}
\hline $\begin{array}{l}\text { Ratin } \\
\text { g }\end{array}$ & $\begin{array}{l}\text { Strongly } \\
\text { Disagre } \\
\text { e }\end{array}$ & $\begin{array}{l}\text { Disagre } \\
\text { e }\end{array}$ & $\begin{array}{l}\text { Neutra } \\
\mathbf{l}\end{array}$ & $\begin{array}{l}\text { Agre } \\
\text { e }\end{array}$ & $\begin{array}{l}\text { Strongl } \\
\text { y Agree }\end{array}$ \\
\hline Scale & 1 & 2 & 3 & 4 & 5 \\
\hline
\end{tabular}

\subsection{Experiment Design}

\section{Dependent Variables}

The dependent variables in this study were the different components of the survey and book searching time and distance measures. The dependent variables were:
a) Administrative office
b) Record room
c) Library
d) Laboratory

\section{Independent Variables}

The independent variables in the present research were time and location. Time had two levels, time A and time B. Time A was before the $5 \mathrm{~S}$ event and time $\mathrm{B}$ was four weeks from the time 5S implementation was complete. Another independent variable was location such as a library, store room, record room, administrative office and laboratories where the survey was carried out at approximately the same time.

The paired t-test helped determine whether the mean scores for the questions at before and after the implementation of $5 \mathrm{~S}$ were statistically different from each other. The t-value was used to further determine the associated p-value. These pvalues were used to evaluate the four hypotheses that were made at the beginning of the study. If the p-value obtained was less than 0.05 then we could reject the first null hypotheses, but if they obtained p-value were greater than 0.05 then the null hypotheses would hold true. The results of the Ttest were used to conclude whether $5 \mathrm{~S}$ increase cleanliness, easiness, workspace, teamwork, productivity and morale of employees. Shows in table 3.3.

Table 3.3 Value's of Cronbach's alpha

\begin{tabular}{|c|c|c|c|c|c|c|c|}
\hline $\begin{array}{l}\text { Cronb } \\
\text { ach's } \\
\text { Alpha }\end{array}$ & $\begin{array}{l}\alpha \\
0.9\end{array}$ & $\begin{array}{l}0.9 \\
>\alpha \\
\geq \\
0.8\end{array}$ & $\begin{array}{l}\mathbf{0 . 8} \\
\alpha \\
0.7\end{array}$ & $\begin{array}{l}> \\
\geq\end{array}$ & $\begin{array}{l}0.7>\alpha \\
\geq 0.6\end{array}$ & $\begin{array}{l}0 . \\
6 \\
> \\
\alpha \\
\geq \\
0 . \\
5\end{array}$ & $0.5>\alpha$ \\
\hline
\end{tabular}




\begin{tabular}{|l|l|l|l|l|l|l|}
\hline $\begin{array}{l}\text { Intern } \\
\text { al } \\
\text { consist } \\
\text { ency }\end{array}$ & $\begin{array}{l}\text { Excel } \\
\text { lent }\end{array}$ & $\begin{array}{l}\text { Go } \\
\text { od }\end{array}$ & $\begin{array}{l}\text { Accep } \\
\text { table }\end{array}$ & $\begin{array}{l}\text { Questio } \\
\text { nable }\end{array}$ & $\begin{array}{l}\text { Po } \\
\text { or }\end{array}$ & $\begin{array}{l}\text { Unacce } \\
\text { ptable }\end{array}$ \\
\hline
\end{tabular}

The questionnaires obtained from the institute employees were used to find out the changes before and after the implementation of $5 \mathrm{~S}$.

\section{RESULTS AND DISCUSSIONS}

The present research was carried out in the different areas of BTIRT. This section presents the results obtained from the questionnaires and the different productivity measures.

\subsection{Outcomes of 5S Implementation}

The 5S event was conducted in higher education institute. As a result of the $5 \mathrm{~S}$ implementation, some changes were made to the college layout and the process.

For this purpose, we change college layout.

- The First-year department is shifted from ground floor to 3rd floor.

- Mechanical department is shifted from 3rd floor to ground floor.

- The Civil department is shifted from the 2 nd floor to the first floor.

- EC and CS department both is shifted from 1st floor to 2nd floor.

\subsection{Travelling Time Analysis}

The data was collected by recording the time with the help of Stopwatch required to travel workshop from the mechanical engineering department before and after implementing 5S.Shows in the table 4.1

Table 4.1 Distance travelled by students in seconds

\begin{tabular}{|c|c|c|}
\hline Student & $\begin{array}{l}\text { Time in second } \\
\text { (Before 5S) }\end{array}$ & $\begin{array}{l}\text { Time in } \\
\text { second (After } \\
5 S \text { ) }\end{array}$ \\
\hline Student 1(2ndyear) & 298 & 119 \\
\hline $\begin{array}{l}\begin{array}{l}\text { Student } \\
\text { year })\end{array} \\
\text { 2(2nd }\end{array}$ & 270 & 101 \\
\hline $\begin{array}{l}\text { Student } \\
\text { year) }\end{array}$ & 286 & 112 \\
\hline $\begin{array}{l}\text { Student } 4(3 r d \\
\text { year })\end{array}$ & 275 & 99 \\
\hline $\begin{array}{l}\text { Student } \\
\text { year) }\end{array}$ & 288 & 104 \\
\hline $\begin{array}{l}\text { Student } \quad 6(3 r d \\
\text { year })\end{array}$ & 299 & 109 \\
\hline Student $7(4$ th year $)$ & 269 & 100 \\
\hline Student 8(4th year) & 295 & 107 \\
\hline
\end{tabular}

\begin{tabular}{|l|l|l|}
\hline Student 9(4th year) & 284 & 102 \\
\hline Faculty Member & 282 & 98 \\
\hline Average & 284.6 & 105.1 \\
\hline
\end{tabular}

\subsection{Book Searching Time Analysis}

The data was collected by recording the time with the help of stopwatch required to searching the book before and after implementing 5S. Shows in the table 4.2

Table 4.2 Book searching time in seconds

\begin{tabular}{|c|c|c|}
\hline Student & $\begin{array}{l}\text { Time in } \\
\text { second } \\
\text { (Before } 5 S \text { ) }\end{array}$ & $\begin{array}{l}\text { Time in second } \\
\text { (After 5S) }\end{array}$ \\
\hline $\begin{array}{l}\begin{array}{l}\text { Student } \\
\text { year) }\end{array} \quad \mathbf{1}(1 \text { st } \\
\end{array}$ & 100 & 53 \\
\hline $\begin{array}{l}\text { Student } \\
\text { year) }\end{array}$ & 116 & 48 \\
\hline $\begin{array}{l}\text { Student } \\
\text { year) }\end{array}$ & 96 & 43 \\
\hline $\begin{array}{l}\begin{array}{l}\text { Student } \\
\text { year })\end{array} \\
\mathbf{4}(2 \mathrm{nd}\end{array}$ & 89 & 35 \\
\hline $\begin{array}{l}\text { Student } \\
\text { year })\end{array}$ & 78 & 27 \\
\hline $\begin{array}{l}\text { Student } \\
\text { year })\end{array}$ & 72 & 21 \\
\hline $\begin{array}{l}\text { Student } \\
\text { year })\end{array}$ & 63 & 16 \\
\hline $\begin{array}{l}\begin{array}{l}\text { Student } \\
\text { year) }\end{array} \\
\end{array}$ & 67 & 12 \\
\hline Library Staff & 61 & 9 \\
\hline Faculty Member & 69 & 11 \\
\hline Average & 81.1 & 27.5 \\
\hline
\end{tabular}

The Table shows that before the implementation of $5 \mathrm{~S}$, faculty, library staff and students takes an average time 81.1 second for searching the books. When $5 \mathrm{~S}$ is implemented and the color-coded system is used then this searching time is reduced to 27.5 seconds. It means 53.6 seconds (around 34\%) will be saved after the implementation of $5 \mathrm{~S}$ which increase productivity.

\subsection{Descriptive Statistics}

The survey was conducted to cover 30 respondents and all respondents return the questionnaire. Hence the respondent rate of this survey was $100 \%$. Once, the data were accumulated, they were categorized into a diverse range of participants with different age, gender, experience, and work area. Shows in the table 4.3

Table 4.3 Respondent's Background

\begin{tabular}{|l|l|l|l|}
\hline Item & Particulars & Frequency & Percentage \\
\hline
\end{tabular}




\begin{tabular}{|l|l|l|l|}
\hline \multirow{3}{*}{ Gender } & Male & 22 & 73.3 \\
\cline { 2 - 4 } & Female & 8 & 26.7 \\
\hline \multirow{4}{*}{ Age } & Less than 25 & 9 & 30.0 \\
\cline { 2 - 4 } & $\begin{array}{l}\text { Between 26 to } \\
\text { 35 }\end{array}$ & 11 & 36.7 \\
\cline { 2 - 4 } & More than 35 & 10 & 33.3 \\
\hline \multirow{4}{*}{$\begin{array}{l}\text { Work } \\
\text { experience }\end{array}$} & $\begin{array}{l}\text { Less than 5 } 5 \\
\text { years }\end{array}$ & 9 & 30.0 \\
\cline { 2 - 4 } & $\begin{array}{l}\text { G to 15 years } \\
\text { years than 15 }\end{array}$ & $\mathbf{1 2}$ & $\mathbf{4 0 . 0}$ \\
\hline \multirow{4}{*}{$\begin{array}{l}\text { Work } \\
\text { area }\end{array}$} & Academic & 10 & 30.0 \\
\cline { 2 - 4 } & $\begin{array}{l}\text { Admin/ } \\
\text { Management }\end{array}$ & 10 & 33.3 \\
\cline { 2 - 4 } & Other & 10 & 33.3 \\
\hline \multirow{2}{*}{ 4.5 Question }
\end{tabular}

4.5 Questionnaires Results and Hypothesis Evaluation

A paired t-test was performed to compare the mean scores, standard error and standard deviation for the subcategories from time $\mathrm{A}$ and $\mathrm{B}$. The comparison of these values of the subcategories from time A (before 5S) and B (after 5S) are shown in the figure.

\subsubsection{For Administrative Office Arrangement}

Null hypothesis was rejected. Arrangements in administrative office before implementation of $5 \mathrm{~S}(\mathrm{M}=28.17, \mathrm{SE}=0.353)$ than to after implementation of $5 \mathrm{~S}(\mathrm{M}=31.87, \mathrm{SE}=0.321), \mathrm{t}$ $(29)=-15.703, p<0.05$. The $t-$ test result shows that increase in arrangement after implementation of $5 \mathrm{~S}$.

\subsubsection{For Storeroom Arrangement}

Null hypothesis was rejected. Arrangements in store room before implementation of $5 \mathrm{~S}(\mathrm{M}=22.67, \mathrm{SE}=0.399)$ than to after implementation of $5 \mathrm{~S}(\mathrm{M}=26.17, \mathrm{SE}=0.336), \mathrm{t}(29)=-$ $18.394, \mathrm{p}<0.05$. The $\mathrm{t}$-test result shows that increase in arrangement after implementation of $5 \mathrm{~S}$.

\subsection{3 for Library Arrangement}

Null hypothesis was rejected. Arrangements in library before implementation of $5 \mathrm{~S}(\mathrm{M}=38.30, \mathrm{SE}=0.359)$ than to after implementation of $5 \mathrm{~S}(\mathrm{M}=41.23, \mathrm{SE}=0.294), \mathrm{t}(29)=-$ 13.063, $\mathrm{p}<0.05$. The $\mathrm{t}$-test result shows that increase in arrangement after implementation of $5 \mathrm{~S}$.

4.5.4 for Laboratories Arrangement

Null hypothesis was rejected. Arrangements in laboratories before implementation of $5 \mathrm{~S}(\mathrm{M}=32.93, \mathrm{SE}=0.395)$ than to after implementation of $5 \mathrm{~S}(\mathrm{M}=35.97, \mathrm{SE}=0.388), \mathrm{t}(29)=-$ 17.906, $\mathrm{p}<0.05$. The $\mathrm{t}$-test result shows that increase in arrangement after implementation of $5 \mathrm{~S}$.

\section{Mean Score of Particular}

- Before 5S Implementation

- After 5S Implementation 41.23
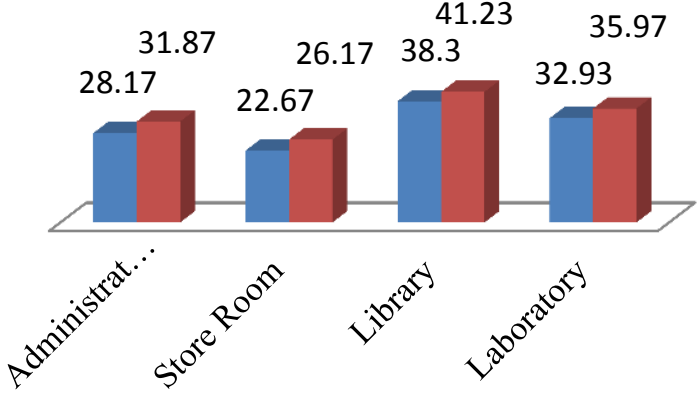

Graph 4.5 Summary of mean score of particular

\section{CONCLUSION}

This study has provided evidence that $5 \mathrm{~S}$ is a great way to assist this organization. $5 \mathrm{~S}$ provides a method to rearrange the layout and improve the discipline. The $5 \mathrm{~S}$ implemented in this study successfully improved the efficiency of the employees.

The $5 \mathrm{~S}$ organized store room, record room, and library so that the time spent finding any item was reduced. By streamlining the library and computer lab, the available blank space was used to create a new digital library and an additional computer lab. By changing the layout, the front office is now quite bigger than before and there is enough room for visitors to sit. Students and faculty members now have to travel a short distance to move from one place to another.

Our 5S implementation in BTIRT SAGAR improves and benefited the BTIRT campus with delicate employee confidence, better joint effort among departments, bridging faculty-staff culture, increased quality from a customer point of view and continuous growth of everyone who is part of a higher education institute.

\section{REFERENCE}

[1] Ali M. and. Shastri R.K. (2010). Implementation of Total Quality Management in Higher Education. Asian Journal of Business Management, 2 (1), pp. 9-16.

[2] Dukkipati U. (2010). Higher Education in India: Sustaining Long-Term Growth. Washington DC: Center for Strategic and International Studies.

[3] McKinsey \& Company (2007). The 'Bird of Gold': The Rise of India's Consumer Market. McKinsey Global Institute.[Online]http://www.mckinsey.com/mgi/reports/p dfs/india_consumer_market/MGI_indiaconsumer full_report.pdf 


\section{International Journal of Engineering Applied Sciences and Technology, 2019 \\ Vol. 4, Issue 4, ISSN No. 2455-2143, Pages 55-62 \\ Published Online August 2019 in IJEAST (http://www.ijeast.com)}

[4] Nash A.M., Poling S. R., and Ward S. (2006). Using Lean for Faster Six Sigma Results a Synchronized Approach. New York, USA: Productivity Press. p. 17.

[5] Lista (2006). Implementing 5S Workplace Organization Methodology Programs in Manufacturing Facilities. White Paper 2006

[6] Yeh D.H.M. (2008). Just-In-Time Manufacturing. MGT2405, University of Toronto.

[7] Boca G.D. (2011). Kaizen Method in Production Management. North University Baia Mare, International Scientific Conference.

[8] Razzak R.A. (2013). 5S for Offices. [Online]. Available:http://www.rumane.com/press/art_publcation1. pdf( pp. 1-3)

[9] Kilpatrick Jerry (2003). Lean Principles Utah Manufacturing Extension Partnership.

[10] Titu M.A., Constantin O., Daniel G. (2010). Applying the Kaizen Method and the 5S Technique in the Activity of Post-Sale Services in the Knowledge-Based Organization. International Multi Conference of Engineering and Computer Scientists 2010 vol.3, IMECS 2010, March 1719, 2010, Hong Kong.

[11] Veza I., Gjeldum N., \& Celent L. (2011). Lean Manufacturing Implementation Problems in Beverage Production Systems. International Journal of Industrial Engineering and Management, 2(1), 21-26.

[12] Santamaria Moral Eugenia (2012). Implementation Selected Tools of Lean Manufacturing. [online] https://upcommons.upc.edu/handle/2099.1/20320

[13] Khamis M.N.A.R., Jamaludin K.R., Ismail A.R., Ghani J.A., Zulkifli R. (2009). Development of 5S Practice Checklist for Manufacturing Industry. In World Congress on Engineering. London, UK.

[14] Prabwo, Noeradji (2011). 5S: Workplace Organization and Standardization. Retrieved from http://www.plantmaintenance.com/articles/5S.pdf

[15] Olofsson Oskar. (2010). 5S Implementation. Retrieved from http://worldclassmanufacturing.com/5S/5S_3.html

[16] Cooper K., Keif M., \& Macro K. (2007). Lean Printing Pathway to Success. Sewickly, PA, USA: PIAIGATF Press.

[17] Shil N.C. (2009). Explicating 5S: Make You Productive. Interdisciplinary Journal of Contemporary Research in Business, 1(6), (PP 33-47).

[18] Wu N.L., Parfenyuk Y., Craig A.S., Craig M.E. (2011). Guidelines for Sustaining a High Level of Success When Implementing Lean Principles in Businesses: Some Successful Case Summaries. International Journal of Accounting Information Science \& Leadership. 4(10), (PP 67-85).

[19] Khamis M.N.A.R., Jamaludin K.R., Ismail A.R., Ghani J.A., Zulkifli R. (2009). Development of 5S Practice Checklist for Manufacturing Industry. In World Congress on Engineering. London, UK.

[20] Gapp R., Fisher R., \& Kobayashi K. (2008). Implementing $5 \mathrm{~S}$ within a Japanese Context: An
Integrated Management System. Emrald Insight, 46 (4), (PP 565-579).

[21] Jiménez M., Romero L., Domínguez M., Espinosa M.M. (2015). 5S Methodology Implementation in the Laboratories of an Industrial Engineering University School. Safety Science 78, (pp. 163-172)

[22] Johana Y., Hardi N.M., Abdullah L., Jumadi N., Mohammad W.N.S.W., Taharuddin N.S. (2014). The Sustainability of QE/5S Implementation in an Administration Office of a Higher Education Institution. https://www.researchgate.net/publication/278244980

[23] Radnor Z., Bucci G. (2011). Analysis of Lean Implementation in UK Business Schools and Universities. ISBN 978-0-9567461-1-5.

[24] Maggie L., Liu Y. (2006). Library as Place. Implementation of $5 \mathrm{~S}$ System. Journal of East Asian Libraries, No. 139.

[25] Skaggs Todd (2010). Essential in Lean Manufacturing is the 5-S Philosophy. Retrieved From http://www.tpmonline.com!articles on totalproductivemaintenance/ leanmfg/5sphilosophy.html

[26] Maidhili S., Meenambika G., Nithyanandam K. (2014). Application and Usefulness of 5S and KAIZEN for Library Space Management. Library Space and Content Management for Networked Society, Bangalore.

[27] Economic Surveys and Budget Documents (2016) [Online] http://indiabudget.nic.in.

[28] Prasad H.A.C., Sathish R., Singh Salam Shyamsunder (2014). Emerging Global Economic Situation: Opportunities and Policy Issues for Services Sector. Government of India, Ministry of Finance, Department of Economic Affairs, Economic Division, www.finmin.nic.in, Working Paper No. 1/2014-DEA

[29] Brady G. (2014). Interview. Study the experience of the KBR, November 2014, Svetogorsk, Russia. Thesis by Sergey Klementev on "Implementation of the 5S Model as a Source to Increase Labor Productivity and as a Platform for the Continuous Improvements for SPPM" Saimaa University of Applied Sciences.

[30] Olofsson O. (2015). Succeeding with 5S. Published by WCM Consulting Ab.

[31] Ho, S. (2007). Business Excellence through 5-S and 6Sigma. Oxford Business \& Economics Conference, ISBN: 978-0-9742114-7-3.

[32] Naman Shrivastava, Ashish Vishwakarma, Nitin Vishwakarma (AUG 2016)," Development of Value Stream Mapping Framework With Fuzzy QFD” (IRJET) e-ISSN: 2395 -0056 (PP 1944-1947). 